\title{
Uncharacterized Protein CXorf67
}

National Cancer Institute

\section{Source}

National Cancer Institute. Uncharacterized Protein CXorf67. NCI Thesaurus. Code C111979.

Uncharacterized protein CXorf67 (503 aa, $52 \mathrm{kDa}$ ) is encoded by the human CXorf67 gene. This protein has no known function. 